\title{
THE IMAGE OF FLIGHT ATTENDANTS FROM THE FLIGHT ATTENDANTS AND AIRLINE CONSUMERS' POINTS OF VIEW
}

\author{
Deborah N. Simorangkir
}

Swiss German University, Tangerang, Indonesia

\author{
Article Information \\ Received: 22 June 2020 \\ Accepted: 29 March 2021 \\ Published: 5 July 2021 \\ DOI: $10.33555 / \mathrm{embm} . v 8 \mathrm{i} 1.155$ \\ Corresponding Author: \\ Deborah N. Simorangkir \\ Tangerang, Indonesia \\ Email: deborah.simorangkir@sgu.ac.id
}

ISSN 2338-8854

eISSN 2620-9918

\begin{abstract}
The flight attendant profession is dominated by women, which may lead to the notion that this profession is one of the few in which women are not experiencing gender discrimination. However, research findings have shown that over time, feminization leads to a decline in status and remuneration, and thus must be understood and monitored because it may be camouflaging the continuous reality of gender inequity. This research seeks to answer these questions: 1) How do Indonesian flight attendants perceive the image of flight attendants as perceived by other Indonesians? and, 2. How do Indonesians perceive the image of flight attendants? The objective of this paper is to revisit the issue of gender stereotypes in flight attendants given new views of what makes for effective flight attendance. This research uses quantitative survey and in-depth interview methods. Three Indonesian flight attendants from major Asian airlines were interviewed to analyze their perceptions of their profession and how they think Indonesia society views them. A survey was also conducted on 100 Indonesians to analyze their perception on the identity of flight attendants. Interview results show that while, flight attendants believe that Indonesian society still cling on to the old images of flight attendants as air hostesses who are often regarded as sex objects, whereas survey results actually show that this image has changed.
\end{abstract}

Keywords: Feminization, Flight Attendant, Gender Stereotype, Identity, Stigma 


\section{Background}

Men have traditionally dominated the travel sector, and only in the late twentieth century did women start to increasingly join it. Ever since, educated women have been recruited to perform a type of domestic labor on ships and planes. These women were at the beginning introduced as stewardesses, and today are called cabin crew or flight attendants. In fact, the first stewardesses in America were nurses, who were hired to serve passengers food, drink, chewing gum, ear plugs, ammonia capsules and, were prepared to administer first aid in emergency cases. In other words, these women were hired because they could alleviate the passengers' fear of flight by domesticating the flight experience (Lyth, 2009). Having gone through many image transformations over time, however, flight attendants acquired a distinct glamorous image, often overshadowing their qualifications. This image somehow still lingers in the perception of many today, especially in Asian countries, such as Indonesia.

Prior to the Second World War, the main objective of airline advertising was to portray flying as a safe means of transportation, thus hiring women was an effective strategy when American Airlines advertised in 1937, asking 'Afraid to fly?'. The message was, if women were not afraid to fly, neither should their husbands. Other airlines soon began to use women in their advertising, depicting flying as a comfortable and reliable means of transport. The message worked for both men's masculinity and women's appetite for modernity (Lyth 2009; Barry, 2007).

Eventually, men also entered the flight attendant profession. However, as a traditionally feminine profession, its history has been filled with legal challenges and regulation changes. One example is the Equal Employment Opportunity Commission (EEOC) in the US in 1968, for marital restrictions on female flight attendants in violation of Title VII, and the 1976 lawsuit under EEOC filed by seven Ozark Airlines, who called themselves the 'Fat Seven', against weight restrictions. They argued that the restrictions were sexist because they only applied to female flight attendants (Whitelegg, 2001).

Two decades later, in 1997, the International Transport Worker's Federation (ITF) started an anti-sexism campaign against the portrayal of the 'exotic mystique' of female flight attendants by Asian airlines, especially Thai International, Korean Air, Cathay Pacific and Singapore Airlines (Whitelegg, 2001). The campaign used a poster illustrating a blow-up doll wearing a flight attendant uniform, with the caption: 'If an airline treats its employees like this, what must it think of its passenger?' Indeed, the exploitation of the exotic orientalism in the 1990s was a result of the increasingly steep competition among Asian airlines and Western airlines. For instance, Cathay Pacific promised to give 'Service straight from the heart' with uniforms, portraying their 'modern Asian image'; and most notably, Singapore Airlines, with its 'Singapore girls', advertising 'girls from the heart, with Asian value, Asian charm, warmth and friendliness' (Whitelegg, 2001). Aside from the competition with Western carriers, these Asian airlines were also in competition with each other, leading to Thai International reducing the maximum age for female flight attendants to forty-five in 1997, in order to challenge Singapore Airline's youthful image (Whitelegg, 2001). The main message of the ITF campaign was that the main duty of the cabin crew was to ensure safety and not to serve drinks, or to be fashionable. This campaign effectively pushed airlines companies all over the world to treat cabin crews as safety professionals who are vital to the operations of airlines. Consequently, EasyJet stopped using its 'I'm easy' t-shirt uniforms, and Crossair, which employed only female cabin crews was under heavy scrutiny (Whitelegg, 2001). 
The early flight attendants may have found flying rewarding because of its novelty, whereas from the 1940s to the 1970s, flight attendants viewed flying as an adventurous lifestyle before married life. After the 1970s, however, it became more common for married women to continue working and pursue a career. Based on the evolution of the flight attendant profession and its changing image portrayal, especially in Asian carriers, this article seeks to analyze how Indonesians perceive the image of flight attendants, but firstly, how Indonesian flight attendants think Indonesians perceive them. In doing so, this article seeks to analyze the experience of Indonesian flight attendants who work for different Asian airlines.

According to renowned sociologist Erving Goffman (1963), social stigma is an attribute or reputation that demeans an individual socially, "society establishes the means of categorizing persons and the complement of attributes felt to be ordinary and natural for members of each of these categories". There are two categories of stigma and its effects: public and selfstigma. Whereas public stigma are stereotypes, prejudice, and discrimination, self-stigma, on the other hand, is when the person not only is aware of the stereotypes attributed to a stigmatized group and agree with them. Moreover, the person must apply these stereotypes to himself.

Recent scandals involving a certain Indonesian airline has resurfaced the old stereotypes about flight attendants. Therefore, this article aims find out whether there are stigmas that pertain to flight attendants today in the minds of Indonesians, and whether these flight attendants experience self-stigma. In order to do so, this article seeks to answer the following research questions:

1. How do Indonesian flight attendants perceive the image of flight attendants as perceived by other Indonesians?
2. How do Indonesians perceive the image of flight attendants?

\section{Research Methods}

In order to answer the research questions, in-depth interviews were conducted with three flight attendants of Indonesian nationality, who work for different Asian carriers; and then a survey was conducted to find out the perceptions of Indonesians toward flight attendants.

In order to answer the first research question, interviews with three Indonesian flight attendants were conducted. The profiles of the respondents are as follow:

\section{AL: Age 28; Singapore Airlines;} Bachelor degree in International Relations; 6 years of experience as flight attendant.

2. PT: Age 32; Cathay Pacific Airways; Bachelor degree in Tourism and Travel; 8 years of experience as flight attendant.

3. GL: Age 24; Garuda Indonesia; Bachelor degree in Marketing Communications; 2 years of experience as flight attendant.

On the other hand, in order to answer the second research question, a survey was conducted on of 100 Indonesians, currently residing in Indonesia, who consider themselves airline consumers. Table 1 describes the profile of the respondents.

Table 1. Profile of Respondents

\begin{tabular}{ccc}
\hline \multirow{2}{*}{ Sex } & Male & $\begin{array}{c}\text { Percentage } \\
(\mathbf{N = 1 0 0})\end{array}$ \\
\hline \multirow{2}{*}{$\begin{array}{c}\text { Highest } \\
\text { level of } \\
\text { education }\end{array}$} & Female & 25 \\
\cline { 2 - 3 } & High School & 75 \\
\cline { 2 - 3 } & Bachelor degree & 35 \\
\cline { 2 - 3 } & Master degree & 46 \\
\hline \multirow{3}{*}{ Age } & Doctoral degree & 6 \\
\cline { 2 - 3 } & <20 yo. & 21 \\
\cline { 2 - 3 } & $20-29$ yo. & 43 \\
\cline { 2 - 3 } & $30-39$ yo. & 28 \\
\cline { 2 - 3 } & $40-49$ yo. & 5 \\
\cline { 2 - 3 } & $50-59$ yo. & 2 \\
\cline { 2 - 3 } & 60 & 1 \\
\hline
\end{tabular}

An online survey was conducted on 100 
The variable measured is the perception of airline consumers toward flight attendants. Using an online Likert-scale questionnaire, these respondents were asked to rate how much they agree with statements that describe their perceptions about flight attendants. The statements portray the various images described earlier: nurse, safety professional, servant, hostess, sexual object, and mother. Because this research only seeks to conduct a univariate analysis to list the perceptions of airline consumers, therefore factor analyses and hypothesis tests are not needed.

\section{Findings and Discussion}

\section{A. The Feminization and Sexualization of the Flight Attendant Profession}

As mentioned earlier, the early stewardess served as an effective advertising proposition that if women are not afraid to fly, no self-respecting man would admit that he is afraid. Having the ability to calm the passengers, the stewardess was in fact hired because of her sex, and this was the beginning of air transport's domestication and feminization (Lyth, 2009).

The first stewardess, Ellen Church, was employed in 1930 by the Boeing Air Transport Company - later known as United Airlines. Soon after, eight other women joined United and in the following years most American domestic airlines had hired female flight attendants. During the Second World War, there was a shortage for medical personnel, thus airlines no longer required stewardesses to be trained nurses. Hence, airline advertisements no longer portrayed stewardesses as nurses in action during an emergency, instead they were portrayed the gracious air hostess welcoming passengers into her home. This portrayal continued on after the war (Lyth, 2009).

By 1965 the airline stewardess had become the typical "woman's job", largely because airlines were hiring significantly more women than men to perform the air 'hostess' role. As a traditionally feminine profession, the stewardess / flight attendant profession fell under the same category of feminized occupations as that of librarians, nurses, and elementary school teachers. Before 1900 , at least $70 \%$ of all librarians, nurses, and elementary school teachers were women. And today, these occupations remain predominated by women as they do not pay enough to appeal men (Kanter,1983). These feminized professions have grown rapidly as the demand for female workers have increased - arguably because they are cheaper - and the number of educated women seeking to pursue careers have also multiplied. As a consequence, the number of women entering feminized professions keeps growing (Hoffman, 1982; Kanter, 1983). And these professions are usually linked to the traditional female roles, which include nurturance, caring, and socializing (Broverman, 1980). These necessary skills at which female flight attendants were deemed to excel are what Arlie Hochschild (2003) calls 'emotional labor'. The flight attendant is expected to be constantly smiling and excellent in her demeanor, even when dealing with rudeness or abuse from passengers, and apparently, this is easier for women than for men (Hochschild, 2003; Whitelegg, 2001; Lyth, 2009). In America and Europe, this 'emotional labor' was what elevated the flight attendant from 'cabin pacifier' to 'service professional'. As such, she was continuously depicted in airline advertisements as the perfect hostess gracefully welcoming passengers on board, organizing logistics of passengers with army precision, yet as warm as a hostess welcoming guests to her home (Lyth, 2009).

One of the principal downsides of the feminization of a profession is the sexualization of its practitioners. Barry (2007) explains the sexualized depictions of stewardesses in the 1970s airline advertisements, using such slogans as 'Fly me' or the 'air strip' campaign. Though the 1970s are 
notably marked by anti-discrimination campaigns by union activist battling the sexualization of flight attendants in pop culture, until now there is still controversy when it comes to the popular depiction of flight attendants.

The pioneer stewardesses of the 1930s were women with excellent appearance and hostess skills, but were also brave skilled nurses who were not afraid to fly. They were marketed for their feminine characteristics - nurturing, subordinate, charming, graceful, and attractive. Therefore, these women were perceived as beautiful airborne waitresses (Lyth, 2009; Barry, 2007). In the 1950s, with faster and bigger jet planes, flight attendants not only needed to be physically attractive, and provide comfort to the passengers, they now had to serve more passengers and diverse travelers in less time. Hence, many turned to labor unions to battle exploitation and gain recognition as safety professionals. However, the courts frequently favored the employers' claims that the presence of female flight attendants was necessary entice and maintain customers. The air travel industry wanted a young, transient, compliant female-dominant workforce (Barry, 2007).

Whitelegg (2001) analyzes the history of female cabin crew in the context of 'emotional labor', whereby traits that are traditionally considered feminine, such as gentle, charming, sensitive, and nurturing, are turned into commodity. Thus, in the cabin, a flight attendant is expected to perform 'women's work' - a commercialized version of the caring and service activities carried out for centuries in the home sphere. Emotional labor develops as a result of the appropriation of sexual difference, in which women are employed to make use of their 'natural' skills. As Tyler and Abbott (1998) argues, "flight attendants are required to deploy "skills" and competencies which they are deemed to possess certainly by means of virtue of their sexual distinction from men". Similarly,
Hochschild (1983) describes emotional labor as the "management of feeling to create a publicly observable facial and bodily display". The objective is to maintain an outward appearance that pleases the customer.

\section{B. Images of Flight Attendants}

The use of image has played an essential role in the advertising of air travel industry, because without it, there is little product distinction that could differentiate one airline from its rivals. Many airlines fly the same planes at the same speed to the same destinations, and often offer the same level of service quality (Lyth, 2009). The image of Singapore International Airlines (SIA), for instance, revolves around its 'Singapore girls'. This image was so well known that in 1993 a replica of the 'girl' was the first business icon featured in Madame Tussaud's museum in London (Whitelegg, 2001).

In the 1950s, US airline advertising and marketing portrayed the image of flight attendants as properly geared up hostesses with perfect military-like uniforms. The ideas were to portray the precision and perfection of the aircraft in order to reassure the passengers that they are safe. In the 1960s, however, the product differentiation shifted to cabin service, and the welcoming smile became increasingly sexualized. The profession of airline hostess became glamor job. In fact, the marketing strategy until the 1970s, in essence, was to say: Our girls are prettier than yours! Flight attendants increasingly protested the sexually charged image that their employers required them to convey because they found it degrading and often led to harassment by male passengers. In the 1970s, the imagery of flight attendants is that of women's liberation, and the entry of girls into professions traditionally reserved to men. If 'father' used to be a default photo for air transport in its early years, then 'mother' has been the most profitable image of the flight attendant in the history of airline advertising. The 
endless work of airline cabin crew is 'mothers' work' (Lyth, 2009).

However, with the transformation of air transport into a mass-market service industry, it is easy to be absorbed in the way they impart their service in the manner of a fine restaurant or hotel, and forget that it is really in the transport business. While the flight attendant is no longer the iconic machine of airline branding, the emotional labor remains. Women's 'emotional capital' not provided air transport industry with an advertising template in previous years, it also contributed to the feminization of the industry, by making flying as routine as a 'mothers' work'.

\section{In-depth Interviews with Flight} Attendants

The three respondents claimed that they were initially interested in becoming flight attendants because of the travelling it involves and how the profession was portrayed in various media such as novels and TV programs. Most importantly, these respondents were influenced by members of their families:

"It was a while after I graduated from my university, then I had a curiosity to try the interview for SIA and Emirates flight attendant. I was keen because of their privilege to travel around the world, being paid for it, and to encounter different unique culture of people all over the world. My family background played a part too. Because my father is a pilot, I was born and raised closely to the airline culture so it just became natural for me to have an interest to work in the same field as him too" (AL).

"I became interested in being a flight attendant because of my sister who has already been flying for several years" (PT).
Even though all respondents hold bachelor degrees, AL and GL do not feel that a college degree is necessary for their profession, whereas PT feels that a college degree in Hospitality and Tourism should be required:

"I think it is not necessary to obtain a university degree to become one. This job does not require high intellect, but it involves skills that even the highest form of education cannot provide. I do not believe that this job is an easy way out either. We just have to adapt to the company guidelines and procedures, adjust it to the nature of the job, and do it on daily basis. Practice makes perfect" (AL).

"At Garuda Indonesia, where I work, having a high school degree is enough to become a flight attendant...In my mind, an education background is not important, because when we enter the flight industry, whether we hold high school, associate, bachelor's or master's degrees, we are all lay about this field. We are then educated and trained to have knowledge about the flight industry, and our image is shaped according to the company's image. However, having an education level higher than high school, in any major, is an advantage in the flight industry, because as cabin crew, our professionalism is not only judged based on our service, but also on our graciousness when interacting with passengers. For example, Garuda Indonesia passengers are often business people, politicians, or government officials. With my education background, I can interact well with these passengers. Many of these passengers have asked me about my education background and offered me jobs. I think this is one of my advantages that allow me to expand my network, which I know not all my coworkers have" (GL). 
These qualifications are actually still very much in-line with the 'air hostess' role described previously. A college degree is only supplementary because it may enable the flight attendants to interact more eloquently with her 'guests'. Instead, the skills that are deemed necessary qualifications include age and physical requirements, English proficiency, and good caretaking intuitions:

"Besides physical requirements (for example: heights and vision), flight attendant has to be flexible, reliable, discipline, and empathetic. He/she has to have heart to care for people, while at the same time being vigilant and maintain the flight safety and security. $\mathrm{He} / \mathrm{she}$ has to have good initiatives as service provider and caretaker, and ensure that the flight will land safely and happily at the appointed destination. Flight attendants have to have that sixth sense; in this case, it is the heart-ware" (AL).

"The qualifications to become a flight attendant include a minimum age of 18 and maximum age of 27 years, minimum education level is high school, minimum height is 158 centimeters and maximum height is 172 centimeters with an ideal and proportional body weight, not colorblind, and proficient in English" (GL).

After getting hired, all of these flight attendants had to undergo rigorous training procedures:

"I went through three-types of training during the foundation course, which are: safety and security, service, and fleets training. Safety and security trainings mostly are to enable us to always keep guard and being vigilant during the flight from any threats, either internal or external threats. Service trainings gave us guidance and procedures of how to conduct the service in accordance with the company guidelines. Grooming is part of this training too. Fleets trainings were given to us in order to familiarize ourselves with the types of fleets we will work at" (AL).

"Training that I got was aircraft safety, medical first aid, food and beverage and communication. Even until now, every 10 months we have a one-day training to review our aircraft safety which requires a test that we need to pass. basically, the airline wants us to not just a flight attendant who serves food on the plane but we also need to be a doctor or nurse, know our aircraft every single angle of it just for preparation of emergency and know how to deal with difficult passenger" (PT).

Even though the qualifications are those of an ideal 'air hostess', however, the training these flight attendants receive once they are hired are more in-line with the 'safety professional' image that their predecessors long fought for. Therefore, it seems that today's airlines - especially Asian carriers - seek to hire flight attendants who are a combination of both historical images.

As safety professionals who are essential to the operations of an airline, all three respondents agree that their families view their profession positively and are supportive of their career choice, when asked about how they think Indonesian society views flight attendants, all of their answers differ:

\footnotetext{
"I think Indonesian society is still quite old-fashioned in their view of flight attendants. They likely think that flight attendants' career is a glamorous job that everyone can do easily, just by standing on the aisle and look pretty. Society tends to see us as "high-class prostitute" as well” (AL).
} 
"From my experience working for Cathay Pacific, all the Indonesian passengers I have met always have a positive view" (PT).

"Indonesian people who have been passengers of Garuda Indonesia come from various segments. There are some who view us as domestic servants or waitresses, although our main focus is the safety and comfort of the passengers. But there are also many who are aware and respect our profession as cabin crew" (GL).

Indeed, they all agree that Indonesian society views the flight attendant profession as a "no-brainer" but glamorous job. One dominant stigma that exist according to all respondents, however, is that flight attendants are some sort of high-class prostitutes:

"Society has the assumption that being a flight attendant is a no-brainer job. So, when more and more people joined the airline recently, they had that culture shock that this job was not as easy as it seemed. Another stigma is pertaining our high-class glamorous job, which relates us to the "high-class prostitutes". Once I overheard an Indonesian passenger told his friends that "stewardesses are paid to lift up passengers' bags, and that we can be 'booked' for a night or so." Obviously, society has been seeing our job wrongly for a long time" (AL).

"Well its seems to be a stigma for all people who have negative thoughts of a flight attendants around the world, example I hear a lot from people say "oh Flight attendants seems to be sleeping around with cockpit crew or passengers", really not all Flight attendants are like that. It all depends on each Individual in fact I encounter a lot of flight attendant are either looking for a steady relationship, in a relationship or are happily married. And for me, I'm happily married" (PT).

Consequently, sexual harassment is quite common, as two of the three respondents have encountered sexual harassment in their jobs:

"I have been harassed by a passenger once. A Caucasian guy, drank too much liquor on the overnight flight. I was alone in the galley that time, as some of my colleagues have gone for rest. He started talking loudly, pointing fingers, and then reached to hug me. I managed to avoid, and I went to report this case to my complex leader. My male colleagues came to warn him for his actions. The drunken man received warning notice from our Inflight Supervisor. The company has trained us to handle this kind of situation, and so I can be rest assured that I will be protected from this" (AL).

"I have been sexually harassed several times during flights, from a passenger who called me by touching my behind - to whom I then remarked that he should call me by "Miss" or by pressing the Attendant Call button - to coworkers, from a purser to a pilot, who would "accidentally" touch my behind, or would even kiss my cheek. Of course, I scolded them and told them to apologize" (GL).

This perception of flight attendants as sexual objects and the experience of sexual harassment are very similar to the image and experience of flight attendants in the 1970s. Fortunately, unlike in the 1970s, airlines where these respondents work take such misconducts seriously, and have procedures for the cabin crew to report any actions that cause discomfort or are a threat to their safety. 
Moreover, all respondents claim that in their respective airlines, both female and male flight attendants have equal chance to advance in their careers, as well as equal pay. The ratio between female and male flight attendants in these airlines, according to the respondents, is 60:40. Despite the female to male ratio, however, the respondents do not necessarily feel that their profession is a feminine profession because males and females play different roles in their job. It is the nature of the profession that requires significant amount of "emotional labor" (Lyth, 2009; Hochschild, 2003):

"My working environment is on the plane, inside the vacuum tube of recycled air, 40,000 feet above the sea level most of the time. It is by nature, not so 'friendly' to anyone of us. It can affect us physically and mentally. So it is important to always stay fit, and keep positive mindset once I am inside the tube. How to counter the side effect of this working environment, that is the most vital thing" (AL).

All respondents feel that their profession is quite accommodating to female employees:

"I think my working environment is quite friendly to female employees. From the policies point of view, we are allowed to take a one-day menstrual leave. Female cabin crew are given a one-year leave. Aside from that, I'd say that my working environment is quite comfortable for both men and women" (GL).

Yet the most difficult to these respondents is the working schedule that forces them to be away from their families on special occasions:

"We fly on public holidays, Fly on weekends, when time to sleep for most of the people, flight attendants are just getting ready to work..." (PT).
But even though the airline companies do not discriminate the employees, traditionally, male flight attendants have a longer career:

\begin{abstract}
"Basically, female flight attendants, once they are married, they will have children and take care of their family. So their career will stop right there. Some of them will come back flying afterwards, but it will not for long. But for male flight attendants, they tend to fly longer, as they are able to continue their career even though they are married and having children. It is more of the women's responsibilities toward family" (AL).
\end{abstract}

"A long career is defined by the retirement age. My seniors are given the choice to either retire at the age of 46 or 56 . But the retirement age of my batch has been set to 36 years old. Still, based on my observation, many female flight attendants resign right after they get married and have a child" (GL).

They, too, plan to work as flight attendants, they all plan to retire in between 2 to 4 years, stating their desire to build their families and focusing on them as the main reason:

"My plan is to maybe stay as a flight attendant for 2 to 4 more years. Regardless of the positive and negative sides, this job is very fun. After I marry, then I plan to leave my job and focus on my family" (GL).

As discussed previously, one of the latest images of flight attendants is that of 'mother'. It seems that many flight attendants are willing to play the role of 'mother' on the cabin up until they become real mothers, in which they will then transfer to another domestic role.

In many ways, it seems that the respondents are fighting the same battles as their cabin 
crew in the 1990s fought the same battles as their antecedents. Though today airline advertisements, especially those of Asian carriers no longer portray flight attendants as sexual objects, and the airlines have strict policies against sexual harassments, the respondents in this study feel that this sexual imagery still lingers in the minds of the Indonesian society, often leading to sexual harassments - both by cabin crew and by passengers. The respondents also feel that the Indonesian society still views flight attendants as mere servants, instead of safety professionals. In conclusion, the perception that these flight attendants have regarding the way Indonesians view their image is a combination of the way flight attendants were depicted in the past.

\section{Survey of Perceptions toward the Image of Flight Attendants}

Table 2 shows the result of this survey.

Table 2. Perceptions about Flight Attendants

\begin{tabular}{|c|c|c|c|c|c|c|c|}
\hline Statements & $\begin{array}{c}\text { Highly } \\
\text { Disagree } \\
\text { (1) }\end{array}$ & $\begin{array}{l}\text { Somewhat } \\
\text { Disagree } \\
\text { (2) }\end{array}$ & $\begin{array}{c}\text { Neutral } \\
\text { (3) }\end{array}$ & $\begin{array}{l}\text { Somewhat } \\
\text { Agree } \\
\text { (4) }\end{array}$ & $\begin{array}{l}\text { Highly } \\
\text { Agree } \\
\text { (5) }\end{array}$ & Total & $\begin{array}{l}\text { Weighted } \\
\text { Average }\end{array}$ \\
\hline $\begin{array}{l}\text { Flight attendants are essential to } \\
\text { the level of customer satisfaction } \\
\text { of an airline. }\end{array}$ & $\begin{array}{c}0.00 \% \\
0\end{array}$ & $\begin{array}{c}0.00 \% \\
0\end{array}$ & $\begin{array}{c}6.00 \% \\
6\end{array}$ & $\begin{array}{c}37.00 \% \\
37\end{array}$ & $\begin{array}{c}57.00 \% \\
57\end{array}$ & 100 & 4.51 \\
\hline $\begin{array}{l}\text { Flight attendants are essential to } \\
\text { the reputation of an airline. }\end{array}$ & $\begin{array}{c}0.00 \% \\
0\end{array}$ & $\begin{array}{c}1.00 \% \\
1\end{array}$ & $\begin{array}{c}6.00 \% \\
6\end{array}$ & $\begin{array}{c}38.00 \% \\
38\end{array}$ & $\begin{array}{l}55.00 \% \\
55\end{array}$ & 100 & 4.47 \\
\hline $\begin{array}{l}\text { Flight attendants are highly } \\
\text { trained professionals. }\end{array}$ & $\begin{array}{c}0.00 \% \\
0\end{array}$ & $\begin{array}{c}3.00 \% \\
3\end{array}$ & $\begin{array}{c}14.00 \% \\
14\end{array}$ & $\begin{array}{c}48.00 \% \\
48\end{array}$ & $\begin{array}{l}35.00 \% \\
35\end{array}$ & 100 & 4.15 \\
\hline $\begin{array}{l}\text { Flight attendants have to update } \\
\text { their skills on a regular basis. }\end{array}$ & $\begin{array}{c}1.01 \% \\
1\end{array}$ & $\begin{array}{c}3.03 \% \\
3\end{array}$ & $\begin{array}{c}14.14 \% \\
14\end{array}$ & $\begin{array}{c}44.44 \% \\
44\end{array}$ & $\begin{array}{c}37.37 \% \\
37\end{array}$ & 99 & 4.14 \\
\hline $\begin{array}{l}\text { Flight attendants are essential to } \\
\text { the safety of passengers of an } \\
\text { airline. }\end{array}$ & $\begin{array}{c}3.00 \% \\
3\end{array}$ & $\begin{array}{c}3.00 \% \\
3\end{array}$ & $\begin{array}{c}8.00 \% \\
8\end{array}$ & $\begin{array}{c}50.00 \% \\
50\end{array}$ & $\begin{array}{c}36.00 \% \\
36\end{array}$ & 100 & 4.13 \\
\hline $\begin{array}{l}\text { Flight attendants are helpful } \\
\text { servers. }\end{array}$ & $\begin{array}{c}0.00 \% \\
0\end{array}$ & $\begin{array}{c}1.00 \% \\
1\end{array}$ & $\begin{array}{c}19.00 \% \\
19\end{array}$ & $\begin{array}{c}52.00 \% \\
52\end{array}$ & $\begin{array}{c}28.00 \% \\
28\end{array}$ & 100 & 4.07 \\
\hline $\begin{array}{l}\text { The service provided by the } \\
\text { flight attendants is essential to } \\
\text { my preference of airlines. }\end{array}$ & $\begin{array}{c}1.00 \% \\
1\end{array}$ & $\begin{array}{c}8.00 \% \\
8\end{array}$ & $\begin{array}{c}11.00 \% \\
11\end{array}$ & $\begin{array}{c}45.00 \% \\
45\end{array}$ & $\begin{array}{l}35.00 \% \\
35\end{array}$ & 100 & 4.05 \\
\hline $\begin{array}{l}\text { Flight attendants are } \\
\text { professional. }\end{array}$ & $\begin{array}{c}0.00 \% \\
0\end{array}$ & $\begin{array}{c}4.04 \% \\
4\end{array}$ & $\begin{array}{c}16.16 \% \\
16\end{array}$ & $\begin{array}{c}54.55 \% \\
54\end{array}$ & $\begin{array}{c}25.25 \% \\
25\end{array}$ & 99 & 4.01 \\
\hline $\begin{array}{l}\text { My views on flight attendants are } \\
\text { based on my own observations. }\end{array}$ & $\begin{array}{c}4.00 \% \\
4 \\
\end{array}$ & $\begin{array}{c}3.00 \% \\
3 \\
\end{array}$ & $\begin{array}{c}21.00 \% \\
21 \\
\end{array}$ & $\begin{array}{c}40.00 \% \\
40\end{array}$ & $\begin{array}{c}32.00 \% \\
32 \\
\end{array}$ & 100 & 3.93 \\
\hline Flight attendants are elegant. & $\begin{array}{c}0.00 \% \\
0 \\
\end{array}$ & $\begin{array}{c}8.00 \% \\
8 \\
\end{array}$ & $\begin{array}{c}19.00 \% \\
19 \\
\end{array}$ & $\begin{array}{c}51.00 \% \\
51 \\
\end{array}$ & $\begin{array}{c}22.00 \% \\
22 \\
\end{array}$ & 100 & 3.87 \\
\hline $\begin{array}{l}\text { Flight attendants are hard } \\
\text { workers. }\end{array}$ & $\begin{array}{c}1.00 \% \\
1 \\
\end{array}$ & $\begin{array}{c}5.00 \% \\
5 \\
\end{array}$ & $\begin{array}{c}29.00 \% \\
29 \\
\end{array}$ & $\begin{array}{c}45.00 \% \\
45\end{array}$ & $\begin{array}{c}20.00 \% \\
20\end{array}$ & 100 & 3.78 \\
\hline $\begin{array}{l}\text { The flight attendant profession is } \\
\text { a high paying profession. }\end{array}$ & $\begin{array}{c}2.00 \% \\
2\end{array}$ & $\begin{array}{c}7.00 \% \\
7\end{array}$ & $\begin{array}{c}34.00 \% \\
34\end{array}$ & $\begin{array}{c}41.00 \% \\
41\end{array}$ & $\begin{array}{c}16.00 \% \\
16\end{array}$ & 100 & 3.62 \\
\hline $\begin{array}{l}\text { The flight attendant profession is } \\
\text { competitive. }\end{array}$ & $\begin{array}{c}3.06 \% \\
3\end{array}$ & $\begin{array}{c}6.12 \% \\
6 \\
\end{array}$ & $\begin{array}{c}31.63 \% \\
31 \\
\end{array}$ & $\begin{array}{c}47.96 \% \\
47\end{array}$ & $\begin{array}{c}11.22 \% \\
11\end{array}$ & 98 & 3.58 \\
\hline Flight attendants are beautiful. & $\begin{array}{c}0.00 \% \\
0 \\
\end{array}$ & $\begin{array}{c}9.09 \% \\
9 \\
\end{array}$ & $\begin{array}{c}43.43 \% \\
43 \\
\end{array}$ & $\begin{array}{c}35.35 \% \\
35 \\
\end{array}$ & $\begin{array}{c}12.12 \% \\
12 \\
\end{array}$ & 99 & 3.51 \\
\hline $\begin{array}{l}\text { It is difficult to get a job as a } \\
\text { flight attendant. }\end{array}$ & $\begin{array}{c}1.00 \% \\
1 \\
\end{array}$ & $\begin{array}{c}14.00 \% \\
14 \\
\end{array}$ & $\begin{array}{c}32.00 \% \\
32 \\
\end{array}$ & $\begin{array}{c}42.00 \% \\
42 \\
\end{array}$ & $\begin{array}{c}11.00 \% \\
11 \\
\end{array}$ & 100 & 3.48 \\
\hline Flight attendants are intelligent. & $\begin{array}{c}1.00 \% \\
1\end{array}$ & $\begin{array}{c}10.00 \% \\
10\end{array}$ & $\begin{array}{c}43.00 \% \\
43\end{array}$ & $\begin{array}{c}35.00 \% \\
35\end{array}$ & $\begin{array}{c}11.00 \% \\
11\end{array}$ & 100 & 3.45 \\
\hline
\end{tabular}




\begin{tabular}{|c|c|c|c|c|c|c|c|}
\hline $\begin{array}{l}\text { I think that the flight attendant profession is well } \\
\text { regarded by society in general. }\end{array}$ & $\begin{array}{c}1.01 \% \\
1\end{array}$ & $\begin{array}{c}12.12 \% \\
12\end{array}$ & $\begin{array}{c}54.55 \% \\
54\end{array}$ & $\begin{array}{c}28.28 \% \\
28\end{array}$ & $\begin{array}{c}4.04 \% \\
4\end{array}$ & 99 & 3.22 \\
\hline $\begin{array}{l}\text { My views on flight attendants are based on the } \\
\text { firsthand experiences of people I know. }\end{array}$ & $\begin{array}{c}12.00 \% \\
12\end{array}$ & $\begin{array}{c}16.00 \% \\
16\end{array}$ & $\begin{array}{c}20.00 \% \\
20\end{array}$ & $\begin{array}{c}42.00 \% \\
42\end{array}$ & $\begin{array}{c}10.00 \% \\
10\end{array}$ & 100 & 3.22 \\
\hline I prefer to be attended by female flight attendants. & $\begin{array}{c}7.00 \% \\
7\end{array}$ & $\begin{array}{c}15.00 \% \\
15\end{array}$ & $\begin{array}{c}44.00 \% \\
44\end{array}$ & $\begin{array}{c}21.00 \% \\
21\end{array}$ & $\begin{array}{c}13.00 \% \\
13\end{array}$ & 100 & 3.18 \\
\hline $\begin{array}{l}\text { Once a female flight attendant becomes a mother, she } \\
\text { should quit her job. }\end{array}$ & $\begin{array}{c}19.00 \% \\
19\end{array}$ & $\begin{array}{c}19.00 \% \\
19\end{array}$ & $\begin{array}{c}24.00 \% \\
24\end{array}$ & $\begin{array}{c}25.00 \% \\
25\end{array}$ & $\begin{array}{c}13.00 \% \\
13\end{array}$ & 100 & 2.94 \\
\hline $\begin{array}{l}\text { The flight attendant profession is not suitable for } \\
\text { married women. }\end{array}$ & $\begin{array}{c}15.00 \% \\
15\end{array}$ & $\begin{array}{c}24.00 \% \\
24\end{array}$ & $\begin{array}{c}25.00 \% \\
25\end{array}$ & $\begin{array}{c}25.00 \% \\
25\end{array}$ & $\begin{array}{c}11.00 \% \\
11\end{array}$ & 100 & 2.93 \\
\hline $\begin{array}{l}\text { The flight attendant profession is not suitable for } \\
\text { married men. }\end{array}$ & $\begin{array}{c}14.00 \% \\
14\end{array}$ & $\begin{array}{c}26.00 \% \\
26\end{array}$ & $\begin{array}{c}29.00 \% \\
29\end{array}$ & $\begin{array}{c}15.00 \% \\
15\end{array}$ & $\begin{array}{c}16.00 \% \\
16\end{array}$ & 100 & 2.93 \\
\hline $\begin{array}{l}\text { The physical appearance of flight attendants is } \\
\text { essential to my preference of airlines. }\end{array}$ & $\begin{array}{c}17.17 \% \\
17\end{array}$ & $\begin{array}{c}20.20 \% \\
20\end{array}$ & $\begin{array}{c}26.26 \% \\
26\end{array}$ & $\begin{array}{c}26.26 \% \\
26\end{array}$ & $\begin{array}{c}10.10 \% \\
10\end{array}$ & 99 & 2.92 \\
\hline Flight attendants are glamorous. & $\begin{array}{c}7.00 \% \\
7\end{array}$ & $\begin{array}{c}28.00 \% \\
28\end{array}$ & $\begin{array}{c}37.00 \% \\
37\end{array}$ & $\begin{array}{c}25.00 \% \\
25\end{array}$ & $\begin{array}{c}3.00 \% \\
3\end{array}$ & 100 & 2.89 \\
\hline I enjoy looking at flight attendants during flights. & $\begin{array}{c}18.00 \% \\
18\end{array}$ & $\begin{array}{c}14.00 \% \\
14\end{array}$ & $\begin{array}{c}36.00 \% \\
36\end{array}$ & $\begin{array}{c}26.00 \% \\
26\end{array}$ & $\begin{array}{c}6.00 \% \\
6\end{array}$ & 100 & 2.88 \\
\hline $\begin{array}{l}\text { The flight attendant profession is a feminine } \\
\text { profession. }\end{array}$ & $\begin{array}{c}19.00 \% \\
19 \\
\end{array}$ & $\begin{array}{c}22.00 \% \\
22 \\
\end{array}$ & $\begin{array}{c}29.00 \% \\
29 \\
\end{array}$ & $\begin{array}{c}17.00 \% \\
17 \\
\end{array}$ & $\begin{array}{c}13.00 \% \\
13 \\
\end{array}$ & 100 & 2.83 \\
\hline $\begin{array}{l}\text { I think that the flight attenda } \\
\text { underestimated by society in }\end{array}$ & $\begin{array}{c}7.00 \% \\
7\end{array}$ & $\begin{array}{c}32.00 \% \\
32\end{array}$ & $\begin{array}{c}36.00 \% \\
36\end{array}$ & $\begin{array}{c}22.00 \% \\
22\end{array}$ & $\begin{array}{c}3.00 \% \\
3 \\
\end{array}$ & 100 & 2.82 \\
\hline Flight attend & $\begin{array}{c}10.00 \% \\
10 \\
\end{array}$ & $\begin{array}{c}26.00 \% \\
26 \\
\end{array}$ & $\begin{array}{c}40.00 \% \\
40 \\
\end{array}$ & $\begin{array}{c}22.00 \% \\
22\end{array}$ & $\begin{array}{c}2.00 \% \\
2\end{array}$ & 100 & 2.80 \\
\hline $\begin{array}{l}\text { My views on flight attendants are based on articles I've } \\
\text { read on social media. }\end{array}$ & $\begin{array}{c}14.00 \% \\
14 \\
\end{array}$ & $\begin{array}{c}29.00 \% \\
29 \\
\end{array}$ & $\begin{array}{c}25.00 \% \\
25\end{array}$ & $\begin{array}{c}28.00 \% \\
28\end{array}$ & $\begin{array}{c}4.00 \% \\
4\end{array}$ & 100 & 2.79 \\
\hline $\begin{array}{l}\text { I enjoy having conversations with flight attendants } \\
\text { during flights. }\end{array}$ & $\begin{array}{c}14.14 \% \\
14\end{array}$ & $\begin{array}{c}19.19 \% \\
19 \\
\end{array}$ & $\begin{array}{c}45.45 \% \\
45 \\
\end{array}$ & $\begin{array}{c}20.20 \% \\
20\end{array}$ & $\begin{array}{c}1.01 \% \\
1\end{array}$ & 99 & 2.75 \\
\hline $\begin{array}{l}\text { My views on flight attendants are based on movies } \\
\text { and/or TV shows I've watched. }\end{array}$ & $\begin{array}{c}15.00 \% \\
15 \\
\end{array}$ & $\begin{array}{c}31.00 \% \\
31 \\
\end{array}$ & $\begin{array}{c}25.00 \% \\
25\end{array}$ & $\begin{array}{c}24.00 \% \\
24\end{array}$ & $\begin{array}{c}5.00 \% \\
5 \\
\end{array}$ & 100 & 2.73 \\
\hline Flight attendants are sexually promiscuous. & $\begin{array}{c}10.00 \% \\
10 \\
\end{array}$ & $\begin{array}{c}30.00 \% \\
30 \\
\end{array}$ & $\begin{array}{c}43.00 \% \\
43\end{array}$ & $\begin{array}{c}13.00 \% \\
13\end{array}$ & $\begin{array}{c}4.00 \% \\
4\end{array}$ & 100 & 2.71 \\
\hline $\begin{array}{l}\text { Once a male flight attendant becomes a father, he } \\
\text { should quit his job. }\end{array}$ & $\begin{array}{c}22.00 \% \\
22\end{array}$ & $\begin{array}{c}25.00 \% \\
25\end{array}$ & $\begin{array}{l}27.00 \% \\
27\end{array}$ & $\begin{array}{c}16.00 \% \\
16\end{array}$ & $\begin{array}{c}10.00 \% \\
10 \\
\end{array}$ & 100 & 2.67 \\
\hline $\begin{array}{l}\text { My views on flight attendants are based on stories I've } \\
\text { heard about other people I don't know. }\end{array}$ & $\begin{array}{c}19.19 \% \\
19\end{array}$ & $\begin{array}{c}23.23 \% \\
23\end{array}$ & $\begin{array}{c}31.31 \% \\
31\end{array}$ & $\begin{array}{c}24.24 \% \\
24\end{array}$ & $\begin{array}{c}2.02 \% \\
2\end{array}$ & 99 & 2.67 \\
\hline $\begin{array}{l}\text { Once a flight attendant gains significant (body) weight, } \\
\text { he/she is no longer fit for his/her job. }\end{array}$ & $\begin{array}{c}25.00 \% \\
25\end{array}$ & $\begin{array}{c}23.00 \% \\
23\end{array}$ & $\begin{array}{c}20.00 \% \\
20\end{array}$ & $\begin{array}{c}25.00 \% \\
25\end{array}$ & $\begin{array}{c}7.00 \% \\
7\end{array}$ & 100 & 2.66 \\
\hline $\begin{array}{l}\text { My views on flight attendants are based on articles I've } \\
\text { read on print media. }\end{array}$ & $\begin{array}{c}19.00 \% \\
19\end{array}$ & $\begin{array}{c}29.00 \% \\
29\end{array}$ & $\begin{array}{c}29.00 \% \\
29\end{array}$ & $\begin{array}{c}22.00 \% \\
22\end{array}$ & $\begin{array}{c}1.00 \% \\
1\end{array}$ & 100 & 2.57 \\
\hline Flight attendants are flirty. & $\begin{array}{c}12.00 \% \\
12 \\
\end{array}$ & $\begin{array}{c}37.00 \% \\
37\end{array}$ & $\begin{array}{c}37.00 \% \\
37\end{array}$ & $\begin{array}{c}11.00 \% \\
11\end{array}$ & $\begin{array}{c}3.00 \% \\
3\end{array}$ & 100 & 2.56 \\
\hline $\begin{array}{l}\text { The flight attendant profession is a masculine } \\
\text { profession. }\end{array}$ & $\begin{array}{c}19.00 \% \\
19\end{array}$ & $\begin{array}{c}36.00 \% \\
36 \\
\end{array}$ & $\begin{array}{c}37.00 \% \\
37 \\
\end{array}$ & $\begin{array}{c}6.00 \% \\
6 \\
\end{array}$ & $\begin{array}{c}2.00 \% \\
2\end{array}$ & 100 & 2.36 \\
\hline $\begin{array}{l}\text { ghter, I would recommend her to be a } \\
\text { nt. }\end{array}$ & $\begin{array}{c}28.28 \% \\
28 \\
\end{array}$ & $\begin{array}{c}28.28 \% \\
28\end{array}$ & $\begin{array}{c}32.32 \% \\
32\end{array}$ & $\begin{array}{c}9.09 \% \\
9\end{array}$ & $\begin{array}{c}2.02 \% \\
2 \\
\end{array}$ & 99 & 2.28 \\
\hline $\begin{array}{l}\text { Once a flight attendant turns } 30 \text {, he/she is no longer fit } \\
\text { for the job. }\end{array}$ & $\begin{array}{c}36.00 \% \\
36\end{array}$ & $\begin{array}{c}30.00 \% \\
30\end{array}$ & $\begin{array}{c}23.00 \% \\
23\end{array}$ & $\begin{array}{c}7.00 \% \\
7\end{array}$ & $\begin{array}{c}4.00 \% \\
4\end{array}$ & 100 & 2.13 \\
\hline $\begin{array}{l}\text { I have tried flirting with flight attendants during } \\
\text { flights. }\end{array}$ & $\begin{array}{c}63.00 \% \\
63 \\
\end{array}$ & $\begin{array}{c}14.00 \% \\
14 \\
\end{array}$ & $\begin{array}{c}19.00 \% \\
19\end{array}$ & $\begin{array}{c}4.00 \% \\
4\end{array}$ & $\begin{array}{c}0.00 \% \\
0\end{array}$ & 100 & 1.64 \\
\hline $\begin{array}{l}\text { I have tried contacting flight attendants after meeting } \\
\text { them on a flight. }\end{array}$ & $\begin{array}{c}67.00 \% \\
67\end{array}$ & $\begin{array}{c}13.00 \% \\
13\end{array}$ & $\begin{array}{c}15.00 \% \\
15\end{array}$ & $\begin{array}{c}5.00 \% \\
5\end{array}$ & $\begin{array}{c}0.00 \% \\
0\end{array}$ & 100 & 1.58 \\
\hline
\end{tabular}


According to Table 2, respondents mostly agreed with the following statements:

- Flight attendants are essential to the level of customer satisfaction of an airline.

- Flight attendants are essential to the reputation of an airline.

- Flight attendants are highly trained professionals.

- Flight attendants have to update their skills on a regular basis.

- Flight attendants are essential to the safety of passengers of an airline.

- Flight attendants are helpful servers.

- The service provided by the flight attendants is essential to my preference of airlines.

- Flight attendants are professional.

Whereas the statements with which the respondents disagreed the most were:

- Flight attendants are flirty.

- The flight attendant profession is a masculine profession.

- If I had a daughter, I would recommend her to be a flight attendant.

- Once a flight attendant turns 30, he/she is no longer fit for the job.

- I have tried flirting with flight attendants during flights.

- I have tried contacting flight attendants after meeting them on a flight.

It seems that the survey respondents view flight attendants as highly trained safety professionals who not only are essential to the operations of the airline, but are also essential to their preference of airlines. This is not in accordance to the stigma that the interviewees in this study believe come with their profession. Instead, the statements that describe flight attendants as sexual objects are the ones that the respondents least disagreed. Thus, the stigma does not seem to linger in the minds of Indonesians anymore - at least according to this survey. However, even though the flight attendants are the ones who perceived this stigma, this does not constitute selfstigma since self-stigma occurs when the person not only is aware of the stereotypes attributed to a stigmatized group and agree with them, but also applies these stereotypes to herself.

\section{Conclusion}

Commercial air transport took longer to develop compared to other means of transport such as trains and motor transports. What began as something only affordable to the rich has become the pervasive means of transport that is today. Throughout its history, branding has always been an important element to the airline industry, which gave the ability for airline companies to ability to differentiate its products from its competitors. Most importantly through branding, airline companies that would otherwise be offering practically the same products, gained distinct images and identities that are globally recognizable.

This article has discussed the evolution of the portrayals and images of flight attendants, as well as some prevalent issues resulting from these. Throughout its history, campaigns over sexual imagery, trade union protests, and lawsuits have been part of the fight for non-discriminatory practice. Still, there are some differences in different regions. For instance, though Asian carriers no longer depict their flight attendants as sexual objects, other restrictions such as age, height, and weight are still very common, which is not the case in European carriers.

Therefore, even though the perceptions of the Indonesian flight attendants regarding society's perception toward flight attendants ("high-class prostitutes", "domestic servants", "waitresses" are different from the actual perceptions of Indonesian people ("highly trained professionals", "essential to safety of passengers"), in some ways, the 'oriental 
charm' stereotype still remains. Such stereotypes have long influenced the perceptions of society toward the flight attendant profession and may potentially promote further stereotyping, thus multiplying the problems already faced by women and other groups currently disadvantaged in the profession.

In a highly patriarchal society such as Indonesia, academic and professional goals of women have long been affected by the social construct of femininity. Traditionally feminine traits such as attractiveness, domesticity, and caring highly regarded. While some girls maintain their aspirations during childhood, they later they stumble upon the pressure to get married and leave their careers to become stay-at-home wives. Thus, often young women would pursue a career in which society tells them they excel because of their feminine traits, but only until their real 'domestic careers' begin which is when they get married.

Findings from this study were only applicable to this research and specific respondents. Therefore, results are not generalizable. Further research using quantitative methods involving a larger sample may give a better understanding about the shifting image of flight attendants.

\section{References}

Barry, K. M. (2007). Femininity in flight: A history of flight attendants. Durham, NC: Duke University Press.

Broverman, I. (1980). Sex-role stereotypes: A current appraisal. Journal of Social Issues, 28. pp.59-78.

Goffman, E. (1963). Stigma: Notes on the management of spoiled identity. Englewood Cliffs, N.J.: Prentice-Hall.

Hochschild, A. R. (2003). The managed heart: Commercialization of human feeling. University of California Press.
Hoffman, L. (1982). Early childhood experiences and women's achievement motives. Journal of Social Issues, 28, pp. 129-158.

Kanter, R. M. (1984). Change masters. Simon and Schuster.

Lyth, P. (2009). Think of her as your mother. The Journal of Transport History, 30(1), pp. 1-21.

Tyler, M., \& Abbott, P. (1998). Chocs away: weight watching in the contemporary airline industry. Sociology, 32(03), pp. 433-450.

Whitelegg, D. (2002). Cabin pressure: The dialectics of emotional in the airline industry. The Journal of Transport History, 23(1), pp. 73-86. 